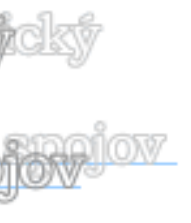

\title{
CENOVÁ REGULÁCIA V SEKTORE POŠTOVÝCH SLUŽIEB
}

\author{
Lucia Madleňáková ${ }^{1}$
}

\section{Úvod}

Prirodzené monopoly spôsobujú problémy nie len tým, že obmedzovaním produkcie znižujú efektivitu výroby, pretože cena, ktorá vedie k maximalizácií zisku je vyššia než marginálne náklady (problém efektivity), ale aj tým, že zarábajú na úkor zákazníka (problém spravodlivosti). Tieto, ale aj iné negatívne aspekty vyvolávané existenciou monopolov vyvíjajú tlak na potrebu ich regulácie. Reguláciu je možné dosiahnut' rôznymi spôsobmi, či už tým, že štát bude priamo vlastnit' či riadit' prirodzené monopoly, alebo sa bude pokúšat' regulovat' len ich ceny.

Obvyklejším prípadom je skôr regulácia prirodzených monopolov, než ich priame vlastníctvo štátom. Väčšina štátov pritom uplatňuje princíp regulácie uznaním ekonomicky oprávnených nákladov a primeraného zisku. Štátom zriadený regulačný orgán zhromažd’uje údaje o nákladoch monopolného subjektu a na základe ich analýzy umožňuje podniku stanovit' cenu pokrývajúcu oprávnené náklady a zahŕňajúcu primeraný zisk. Aj napriek tomu, že tento spôsob cenovej regulácie sa zdá byt' optimálny, má svoje úskalia. Predovšetkým vyvoláva náročné administratívne postupy a časté spory medzi regulátorom a podnikom o tom, ktoré náklady sú skutočne oprávnené a môžu byt' teda zahrnuté do regulovanej ceny. Ďalším problémom je nízka motivácia firiem vedúca $\mathrm{k}$ úspore nákladov, pretože ich zníženie vyvolá v d'alšom období zníženie cien. Problematika regulácie je zložitá a nie je jednoduché vyriešit' ju čo i len v teoretickej rovine. [3]

Výnimkou nie je ani sektor poštových služieb, ktorý sa svojím charakterom blíži $\mathrm{k}$ prirodzeným monopolom, nakol'ko sú pre toto odvetvie charakteristické úspory z rozsahu (tzn. že náklady na vybudovanie celoštátnej poštovej siete sú príliš vysoké nato, aby na tomto území pôsobilo viac poštových podnikov) a rovnako tu existujú úspory zo sortimentu (tzn., že poštový podnik môže prostredníctvom poštovej siete poskytovat' niekol'ko služieb súčasne ovel'a efektívnejšie než iné podniky). Ďalšou charakteristickou črtou je, že v tomto sektore dochádza k obmedzovaniu konkurencie udelením poštovej výhrady verejnému operátorovi. Potreba cenovej regulácie je $\mathrm{v}$ tomto prípade nevyhnutná aj $\mathrm{z}$ dôvodu zabezpečenia výkonu služieb vo verejnom záujme, kde pri cenotvorbe bude potom významnú úlohu zohrávat’aj tzv. sociálna rovina, čiže povinnost' štátu zaistit' poskytovanie univerzálnej poštovej služby za prijatel'né ceny pre všetkých obyvatel'ov na celom území štátu. Cenová regulácia a kontrola cien poštových služieb v SR je plne v kompetencii Poštového regulačného úradu SR. [5]

\footnotetext{
${ }^{1}$ Ing. Lucia Madleňáková, PhD., Katedra spojov, Fakulta prevádzky a ekonomiky dopravy a spojov, Žilinská univerzita v Žiline, Univerzitná 1, 01026 Žilina

Tel. č.: 041/513 3125, fax: 041/ fax: +421/41/5655 615

email: Lucia.Madlenakova@,fpedas.utc.sk
} 


\section{Modely cenovej regulácie}

Cenovú reguláciu je možné realizovat' prostredníctvom rôznych modelov. Pri výbere vhodného modelu je však potrebné brat' do úvahy podmienky v akých sa daný poštový podnik nachádza, tak aby bolo model možné aplikovat'. Je teda potrebné brat' do úvahy [2]:

- štruktúru cenovej regulácie,

- formu cenovej regulácie,

- dobu trvania cenovej regulácie.

\section{Štruktúra cenovej regulácie}

V oblasti poštových služieb je možné hovorit’ o nasledovných štruktúrach cenovej regulácie [2]:

- individuálny strop,

- celkový príjmový strop,

- regulácia priemerných jednotkových cien,

- regulácia prostredníctvom cenového koša,

- hybridná regulácia.

\section{Individuálny strop}

Princíp tejto metódy spočíva v stanovení individuálneho cenového stropu pre každú regulovanú službu. Poštový regulačný úrad by v tomto prípade odhadoval náklady (vrátane primeraného zisku) každej služby a podl'a nich by stanovil jednotlivé ceny. Metóda je vhodná pre regulované podniky s malými fixnými alebo spoločnými nákladmi, kde sú nepredvídatel'né zmeny na úrovni nákladov. Jedna z hlavných výhod individuálnych stropov je, že sú transparentné a predvídatel'né pre zákazníkov, ktorí sa pravdepodobne budú zaujímat' o ceny, ktoré budú musiet' zaplatit', než o celkový príjem, ktorý bude podniku uznaní. Avšak pre podnik typu Slovenská pošta, a.s., s vel'kým množstvom regulovaných služieb a vel'kým podielom fixných nákladov by stanovenie individuálnych cenových stropov pre každú službu bolo vel'mi náročné. Takýto model neposkytuje Slovenskej pošte, a.s., dostatočnú flexibilitu, pokial' ide o zladenie cenovej štruktúry s jej nákladmi. Neposkytuje ani slobodu reagovat' na prípadné zmeny trhového prostredia.

\section{Celkový príjmový strop}

V rámci tejto metódy by sa pre Slovenskú poštu, a.s., stanovil fixný povolený príjem, a to na celé obdobie cenovej regulácie. Zatial' čo celkový príjem zo služieb spadajúcich do cenovej kontroly by bol kontrolovaný, jednotlivé individuálne ceny by záviseli na rozhodnutí Slovenskej pošty, a .s.. Zavedenie tejto metódy by vyžadovalo určenie celkových príjmov na základe predpokladaných nákladov a objemov realizovaných v rámci stanovenej regulačnej periódy $\mathrm{v}$ súlade $\mathrm{s}$ povoleným príjmom pre danú periódu, pričom by sa zohl'adnilo prečerpávanie alebo naopak nevyčerpanie prostriedkov z minulej periódy. Je zrejmé, že takáto cenová kontrola je vhodná pre podniky s vysokým podielom fixných nákladov, ktoré realizujú svoju činnost' v odvetviach s predvídatel'nými objemovými zmenami. Slovenská pošta, a.s., má síce vysoký podiel fixných nákladov, ale realizované objemy sú najmä s nastávajúcou liberalizáciou trhu t’ažko predvídatel'né. Táto neistota by mohla byt' prekonaná použitím rôzne zložitých korekčných mechanizmov. Metóda má však podstatnú nevýhodu v tom, že nemotivuje regulovaný podnik k vyššej aktivite a realizovaným objemom. Regulovaný podnik nie je tlačený do redukcie nákladov, nie je preto vhodné odporúčat' danú metódu ako vhodnú formu regulácie pre Slovenskú poštu, a.s.. 


\section{Regulácia priemerných jednotkových cien}

Ďalším možným prístupom je regulovat' priemerné ceny za jednotku, napríklad za list. Opät' by sa predpokladali objemy a náklady, z nich by sa počítali primerané príjmy a následne priemerné jednotkové ceny regulovaných služieb by sa kalkulovali delením celkových predpokladaných príjmov predpokladanými objemami. Táto metóda by mohla byt' vhodná tam, kde sa náklady líšia vo vzt’ahu k objemu a môžu byt' nepredvídatel'né. Metóda by odstránila nevýhodu celkovej príjmovej regulácie, kde nebolo možné stimulovat' regulovaný podnik k vyšším výkonom. Pri konštrukcii regulácie priemerných jednotkových cien by bolo treba zvážit', či do nej zaradit' všetky služby, alebo aplikovat' rôzne regulácie priemerných jednotkových cien na rôzne služby alebo skupiny služieb. Výhodou je cenová flexibilita, ktorá by regulovanému podniku napr. umožnila viac prispôsobit' ceny nákladom. Avšak cenová flexibilita by mohla mat' aj nežiaduce dôsledky, ak by viedla ku krížovému financovaniu konkurenčných služieb z monopolných činností. Tento problém by sa dal zmiernit' zameraním regulácie na užšie podskupiny služieb alebo individuálne služby. Tým by sa zmiernili výhody cenovej diferenciácie. Nevýhodou tejto metódy je skutočnost', že povolené príjmy by nerešpektovali zmeny $\mathrm{v}$ nákladoch spôsobené zmenami produktového mixu, teda metóda neumožňuje zvýšit' povolený príjem pri prechode na drahšie služby.

\section{Regulácia prostredníctvom cenového koša}

Ako alternatívu k predchádzajúcej metóde je možné použit' reguláciu vážených priemerov cien regulovaných služieb. Na základe predchádzajúceho dopytu po jednotlivých cenovo regulovaných službách by sa v rámci cenového koša „Zvážili“ individuálne cenové zmeny. Regulovaný podnik by musel zaistit', že celková vážená priemerná cenová zmena neprekročí stanovený cenový strop. Metóda je vhodná pre podniky poskytujúce mnoho služieb za individuálne ceny. Metóda by taktiež poskytla regulovanému podniku flexibilitu menit' ceny, aby boli viac v súlade s nákladmi. Cenový kôš, vo vzt'ahu k predchádzajúcemu spôsobu regulácie, by mohol ponúknut' podniku poskytujúcemu množstvo služieb väčšiu stabilitu v rámci cenovej kontroly. Priemerná cenová regulácia je založená na predpovedi realizovaného objemu každej služby a táto predpoved' by mohla byt' nesprávna. Priemerná cena je potom menšia alebo väčšia, ako by mala byt' a v d'alšej regulačnej perióde je nutné uskutočnit' vyrovnanie. Tento problém je tým väčší, čím širšie je portfólio ponúkaných služieb a čím väčšie sú trhové rozdiely v trhových podmienkach medzi nimi. Opät' by bolo potrebné rozhodnút', ktoré služby podrobit' takejto regulácii. Metóda by bola účinnejšia, ak by služby podliehajúce tejto regulácii mali približne rovnakú váhu. V prípade, že by medzi regulovanými službami bolo niekol'ko služieb s vel'kými váhami, znamenalo by to, že ostatné služby nemusia byt' efektívne regulované a v tomto prípade by bolo účelné uvažovat' o posilnení metódy, napr. formou dodatočnej kontroly služieb s najväčšími nákladmi.

\section{Hybridná regulácia}

Jednou z možností zavedenia vhodného modelu cenovej regulácie je skombinovat' predchádzajúce prístupy, čo by sa mohlo vzhl'adom ku zložitosti činnosti Slovenskej pošty, a.s., s jej početnými službami, cenovou diferenciáciou a spoločnými nákladmi javit' ako optimálne. Takáto hybridná štruktúra by napríklad mohla obsahovat' individuálny cenový strop pre zásielky najnižšej hmotnostnej kategórie (t.j. do $20 \mathrm{~g}$ ) v kombinácii s reguláciou cenového koša ostatných služieb či skupín služieb. To by poskytlo Slovenskej pošte a.s., určitú flexibilitu, pokial' ide o zladenie cien a nákladov. Zároveň by bol aplikovaný cenový strop na najviac využívanú službu. Použitím cenového koša by bola zaistená väčšia stabilita cenovej kontroly. 


\section{Forma cenovej regulácie}

Forma cenovej regulácie úzko súvisí so štruktúrou cenovej regulácie. Pre sektor poštových služieb SR je vd'aka špecifickosti možné z teoretického hl'adiska hovorit' o týchto formách cenovej regulácie:

- regulácia stupňa výnosnosti,

- RPI-X regulácia,

- regulácia so zdiel’anými ziskami,

- inflačne založená regulácia,

- hybridná forma regulácie.

\section{Regulácia stupňa výnosnosti}

Regulácia stupňa výnosnosti je koncipovaná tak, aby ceny boli stanovené na úrovni, ktorá umožní regulovanému podniku pokryt' všetky náklady na regulované služby, pričom je do nich zakalkulovaný aj primerane adekvátny zisk. V podstate možno tento prístup nazvat' „cost-plus“. Dovol'uje, aby boli všetky nevyhnutné náklady vrátane zisku pokryté uživatel'om služby. Konkrétne by zavedenie tejto metódy znamenalo pre Počtový regulačný úrad nutnost' stanovit' pre regulovaný podnik mieru výnosnosti kapitálu a garantovat' túto mieru výnosnosti tak dlho, kým bude rozumne investovat'. Ceny by teda boli kalkulované tak, že:

\section{celkové príjmy = celkové náklady + miera výnosnosti}

Hoci by $\mathrm{v}$ rámci tohto prístupu bolo $\mathrm{v}$ kompetencii národného regulačného orgánu stanovenie miery výnosnosti kapitálu, mal by len malý vplyv na celkové príjmy a ceny regulovaného podniku. Náklady by boli premietnuté priamo do cien bez ohl'adu nato, či sú podl'a národného regulačného orgánu efektívne, alebo nie. Ak však regulovaný podnik požiada o zvýšenie cien, národný regulačný orgán začne preverovat' jeho efektívne hospodárenie. Je pravdepodobné, že takýto prístup nevytvára dostatočné stimuly pre regulovaný podnik k dosahovaniu maximálnej efektívnosti. [7]

Výhody:

- garantuje stálu mieru návratnosti investícií, čím podnecuje regulovaný podnik k vyšším investíciám,

- redukuje riziko spojené s investíciami, čím prispieva k znižovaniu kapitálových výdavkov,

- vychádza zo skutočných nákladov regulovaného podniku, čím chráni tento subjekt pred nečakanými zmenami nákladov,

- regulovaný podnik nebude dosahovat' prehnanú výnosnost'.

Nevýhody:

- regulácia môže byt' zdrojom negatívnych podnetov k rastu nákladov najmä vysokými investíciami do kapitálového vybavenia, čo nie je vždy v súlade s podporou efektívnosti a hospodárnosti,

- vyžaduje až príliš podrobnú znalost' regulovaného podniku a jeho nákladov zo strany národného regulačného orgánu, čo vedie $\mathrm{k}$ jeho neprimeranému zasahovaniu do činnosti regulovaného podniku, hlavne do jeho investičných rozhodnutí,

- rovnako, ako u iných foriem regulácie je často t’ažké stanovit' správnu mieru výnosnosti.

Je možné konštatovat', že hoci by regulácia výnosnosti poskytla Slovenskej pošte, a.s., ochranu, pokial ide o mieru návratnosti kapitálu, obsahuje relatívne slabé stimuly k vyššej efektívnosti, a tým $\mathrm{k}$ ochrane zákazníka pred zneužitím jej výnimočného postavenia pri stanovovaní cien. 


\section{$\underline{\text { RPI-X regulácia }}$}

V rámci tohto prístupu by národný regulačný orgán stanovil pre regulačné obdobie (obvykle dlhšie ako v prípade regulácie stupňa výnosnosti) ceny podl’a vzt'ahu:

kde:

\section{RPI - X,}

- RPI (retail price index) - charakterizuje percentuálnu zmenu cien,

- X - faktor reprezentujúci odhad ciel'ového zvýšenia produktivity regulovaného podniku $\mathrm{v}$ priebehu regulačného obdobia.

Zákazníci by v rámci tohto prístupu boli zvýhodnení pri tvorbe cien faktorom $\mathrm{X}$, a to po dobu regulačného obdobia. Na druhej strane by regulovaný podnik získal stanovenú mieru návratnosti kapitálu, pokial' by udržal náklady na úrovni určené danou reguláciou. Pokial' by sa regulovanému podniku podarilo znížit’ náklady o viac ako je stanovené reguláciou, tak by samozrejme získal vyššiu mieru návratnosti kapitálu.

Výhody:

- vzhl'adom k stálosti cien a príjmov regulovaného podniku v krátkom resp. strednom období, poskytuje táto forma cenovej regulácie vel'ký stimul $\mathrm{k}$ redukcii nákladov, budúce aktivity zákazníkov a podniku budú môct' byt' plánované s väčšou istotou a úspory nákladov možno previest' na zákazníka tým, že sa pri d’alšej revízii cenovej regulácie znížia regulovanému podniku povolené príjmy alebo ceny,

- poskytuje záruku predvídatel'nosti reálnych cien po dobu regulačného obdobia a tiež poskytuje jasné a transparentné ciele pre manažment regulovaného podniku,

- ide o zrozumitel'nú a transparentnú formu cenovej regulácie.

Nevýhody:

- úspech RPI - X regulácie závisí na vytvorenej stimulácii zisku a na predpoklade, že regulovaný podnik bude konat' tak, aby maximalizoval hodnotu kapitálu vlastníkov (akcionárov) zodpovedajúcu uvedenej stimulácii; v prípade Slovenskej pošty, a.s., so $100 \%$ podielom štátu je otázne, či bude na uvedenú stimuláciu reagovat' podobne ako súkromný podnik,

- silné stimuly $\mathrm{k}$ redukcii nákladov môžu regulovaný podnik zvádzat' $\mathrm{k}$ dosahovaniu úspory nákladov na úkor kvality poskytovaných regulovaných služieb; preto je nutné pri konštrukcii konkrétnej štruktúry a formy regulácie mysliet' aj na kontrolu kvality poskytovaných služieb,

- pri zavedení tejto formy regulácie je potrebné vel'ké množstvo informácií, pričom Poštový regulačný úrad sa musí väčšinou spoliehat' na regulovaný podnik; ten bude mat' logicky snahu nadhodnocovat' svoje predpokladané výdaje, aby v nasledujúcom regulačnom období získal vyšší povolený príjem; problém je ešte umocnený absenciou podobného konkurenčného podniku ako je Slovenská pošta, a.s., a taktiež nedostatkom porovnatel'ných historických údajov.

RPI - X regulácia by Slovenskú poštu a.s. silne stimulovala k vyššej efektivite a hospodárnosti, čo by sa mohlo na zákazníkov preniest' formou nižších cien. Na druhej strane by poskytovala malú záruku pre rast kvality, a preto by bolo nutné túto formu regulácie doplnit’ špecifickou formou regulácie kvality.

\section{Regulácia so zdiel’anými ziskami}

Charakteristickou črtou tejto formy cenovej regulácie je, že ciele pre podnikové príjmy sú stanovené na niekol'ko rokov dopredu na základe nákladových predpovedí.

Ak by teda skutočné náklady klesli pod predpokladané náklady alebo by príjmy boli vyššie než aké boli predpokladané, v tom prípade by boli úspory rozdelené podl'a vopred stanoveného kl’úča medzi zákazníkov SP, a.s., (tým, že by sa znížil povolený príjem pre d’alšie regulačné obdobie) a akcionárov (tým že by sa zvýšil nerozdelený zisk regulovaného 
podniku). Vzhl'adom na to, že čast' úspor je v dobe ich realizácie prevedená na zákazníkov, možno argumentovat' tým, že nie je nutné preskúmavat' parametre cenovej regulácie tak často ako u RPI - X regulácie. Avšak potenciálne výhody dlhšej doby trvania regulácie by bolo nutné kompenzovat' analýzami relatívnej stálosti trhových podmienok. Výhody:

- zachovanie niektorých stimulov k redukcii nákladov; rozsah stimulov pre regulovaný podnik závisí od výšky podielu úspor, ktoré sú prevedené na zákazníkov; čím väčší podiel úspor je prevedený na zákazníkov, tým sú slabšie stimuly regulovaného podniku k redukcii nákladov,

- $\quad$ úspory nákladov môžu byt' prevedené na zákazníkov hned' po ich realizácii a nie je nutné čakat' na d'alšie nastavenie cenovej regulácie,

Nevýhody:
relatívne jednoducho pochopitel’ná a transparentná forma regulácie.

- $\quad$ slabšie stimuly $\mathrm{k}$ vyššej efektívnosti než v prípade RPI - X regulácie, a to preto, že si regulovaný podnik necháva $100 \%$ dosiahnutých úspor, ale čast' je transformovaná na zákazníkov,

- každoročné nastavovanie úrovne nákladov vyžaduje rovnako vel'ké úsilie Poštového regulačného úradu ako $\mathrm{v}$ prípade periodického cenového overovania $\mathrm{v}$ rámci $\mathrm{RPI}-\mathrm{X}$ regulácie,

- $\quad$ určovanie časti nákladov, ktoré sú prevedené spätne na zákazníkov, je v podstate subjektívne a vyžaduje trojstranné jednanie medzi Poštovým regulačným úradom, zákazníkmi a Slovenskou poštou, a.s.. Poštový regulačný úrad rovnako bude musiet' vysporiadat' s tým, akým spôsobom bude niest' SP, a.s. zodpovednost' za realizáciu strát $\mathrm{v}$ rámci tejto formy regulácie, t.j. či je regulácia symetrická.

Je možné teda zhrnút', že regulácia so zdiel'anými ziskami by poskytovala relatívne slabé stimuly k vyššej efektivite Slovenskej pošty, a.s., v porovnaní s RPI - X reguláciou, ale na druhej strane relatívne stabilné podmienky pre dlhodobé plánovanie podniku. Táto forma regulácie by neposkytovala presný profil cien a taktiež by pri tejto forme zákazníci nezískali takú istotu ako regulovaný podnik.

\section{Inflačne založená regulácia}

V rámci inflačne založenej regulácie sú ceny viazané infláciou, resp. s RPI alebo iným inflačným indexom, ale bez akéhokol'vek vyrovnávania, ktoré by odzrkadl'ovalo ciel'ový nárast produktivity tak, ako je to pri RPI - X regulácii. Ide v podstate o upravenú RPI - X reguláciu, kde $\mathrm{X}$ je rovné nule.

Výhody tejto formy regulácie by boli nasledujúce:

- udržuje konštantné ceny v reálnych hodnotách,

- zaručuje dostupnost' cien pre zákazníkov, lebo ceny sa menia len tak, ako rastú ceny $\mathrm{v}$ ekonomike ako celku.

Aplikácia tejto formy na reguláciu Slovenskej pošty, a.s., by bola tiež spojená s radom nevýhod:

- nezaist'uje väzbu regulovaných cien na náklady, a tak môže podporovat' ceny, ktoré nie sú efektívne a nereflektujú náklady,

- môže viest' $\mathrm{k}$ nadmerným ziskom regulovaného podniku vd’aka značným úsporám z rozsahu, ktoré sú u Slovenskej pošty, a.s. evidentné a vd'aka nim s rastúcim objemom klesajú priemerné jednotkové náklady; tým dochádza k zväčšovaniu nesúladu medzi cenou a nákladmi (teda zas problém väzby cien na náklady).

Ide teda o metódu, ktorá by $\mathrm{z}$ hl'adiska vývinu cien bola prijatel’ná pre zákazníkov, viacmenej vo svojom pasívnom prístupe by bola príliš štedrá k regulovanému podniku, lebo neobsahuje žiadne stimuly k jeho vyššej efektivite. 


\section{Hybridná forma regulácie}

Vyššie uvedené formy regulácie nie sú vzájomne nezlučitel'né a pri ich aplikácii na podnik typu Slovenská pošta, a.s. je možné uvažovat’ o ich kombinácii.

\section{Doba trvania cenovej regulácie}

Vhodná doba trvania cenovej regulácie je závislá na zvolenej forme cenovej regulácie.

V rámci regulácie stupňa výnosnosti by sa príjmy stanovovali každý rok na základe predpokladaných nákladov, k nim by sa pripočítal adekvátny zisk. Regulovaný podnik by mal samozrejme právo žiadat' národný regulačný orgán o zvýšenie nastavenej miery výnosnosti v prípade, že by ju považoval za dlhodobo neadekvátnu. Vd'aka tomu by doba takejto regulácie bola neistá

V prípade RPI - X regulácie by sa stanovili kontroly v intervaloch rádovo niekol'ko rokov (od dvoch do piatich). Po nich by tak bolo možné previest' dosiahnuté úspory prostredníctvom budúcich nižších reálnych cien na zákazníka. Všeobecne platí, že čím kratšia regulačná perióda, tým sú slabšie stimuly $\mathrm{k}$ dosahovaniu úspor. Udržiavanie stálych cien dlhšiu dobu znamená pre podnik, že môže dlhšie využívat' výhody z dosiahnutých nákladových úspor. Naviac dlhšia perióda znamená väčšiu zmenu podmienok, a to vd’aka otváraniu sektoru poštových služieb konkurencii. To by mohlo priniest' neistotu ako pre regulovaný podnik, tak aj pre zákazníka. Je nutné zdôraznit', že navrhovaná cenová regulácia by mala slúžit' ako substitúcia konkurenčného tlaku iba po dobu, pokial' sa konkurenčné prostredie v sektore poštových služieb nerozvinie natol'ko, že samo dokáže ochránit' záujmy zákazníkov. Hlavne ich prístup k základným poštovým službám.

\section{Model cenovej regulácie vhodný pre poštový sektor SR}

V súčasnej dobe ešte sektor poštových služieb v SR nie je na výraznú dereguláciu pripravený. Deregulácia musí prebiehat' postupne, práve preto by sa mala cenová regulácia aplikovat' ako prostriedok k podpore rozvoja konkurencie.

Z vyššie popísaných alternatív štruktúr cenových kontrol sa javí najlepšie variant cenového koša, prípadne kombinácie tejto metódy s individuálnym cenovým stropom, ako je popísaný v rámci hybridnej regulácie. Vyplýva to najmä z toho, že príjmy sa môžu pohybovat' v súlade s nákladmi a model tiež umožňuje regulovanému podniku menit' podl'a potreby ceny $\mathrm{v}$ rámci cenového koša.

Z uvedených foriem cenovej regulácie sa ako najvýhodnejšia pre aplikáciu na podnik typu Slovenská pošta, a.s., javí variant RPI - X regulácia, hlavne pre v nej obsiahnuté silné stimuly k vyššej efektivite a hospodárnosti regulovaného podniku. RPI - X reguláciou možno teda zaistit’ ochranu zákazníkov pred zneužívaním výnimočného postavenia regulovaného podniku pri stanovení cien. Je však nutné eliminovat’ jej slabšiu stránku - chýbajúci tlak na rast kvality - vylepšením kontrolných mechanizmov tak, aby Slovenská pošta, a.s. nedosahovala požadovanú efektivitu cestou znižovania kvality poskytovaných služieb.

Pokial ide o stanovenie periódy v rámci cenovej regulácie Slovenskej pošty, a.s., je optimálne navrhnút', práve vzhl'adom na vel'mi nejasnú situáciu na poštovom trhu, najprv kratšiu periódu (2 roky) s možnost'ou neskôr ju predížit'. Samozrejme len v tom prípade, ak to bude potrebné, ak sa nevytvoria efektívne konkurenčné sily, ktoré zabezpečia stabilitu trhu.

\section{Záver}

Cenová regulácia predstavuje stanovenie alebo priame usmerňovanie výšky cien cenovými orgánmi. Jej primárnym ciel’om v sektore poštových služieb je vylúčenie možnosti zneužitia právomoci držitel'a poštovej licencie prostredníctvom vysokých cien v oblasti 
monopolne poskytovaných služieb (poštová výhrada). A tiež podporit' konkurenciu, zväčšit' tlak na zvýšenie efektivity, ktorá vedie k znižovaniu cien a podporit' neustále zlepšovanie kvality poskytovaných služieb.

\section{Literatúra}

[1] BORKOWSKI, S., ČOREJOVÁ, T.: Instrumenty rozwiazywania problemów w zarzadzaniu. Wydawnictwo Wyzszeh Szkoly Zarzadzania i Marketingu w Sosnowcu, 2004, ISBN 83-89275-46-5

[2] FRANK, R. H., BERNANKE, B. S.: EKONOMIE, GRADA Publishing. Praha 2003, ISBN 80-247-0471-4

[3] HODÁKOVÁ, M.: Liberalization and postal regulation in the Central and Eastern European countries In: Studies of Faculty of Operation and Economics of Transport and Communications of University of Žilina : Volume 21. - Žilina: University of Žilina, 2004. - ISBN 80-8070-274-8. - S. 77-83.

[4] MADLEŃÁK, R.: The role of the postal enterprises at the electronic marketplace In: Telekomunikacja i poczta jako stymulatory rozwoju e-gospodarki w Polsce : Szczecin - Darłowo, maj 2005. - Szczecin: Wydział Zarządzania i Ekonomiki Usług, Uniwersytet Szczeciński, 2005. - ISBN 83-7241-477-7. - P. 169-174.

[5] MADLEŇÁKOVÁ, L: K problematike vecnej a cenovej regulácie poštových služieb In: Pošta, Telekomunikácie a Elektronický obchod: elektronický časopis Katedry spojov. ISSN 1336-8281. - [Roč. 1, č. 1] (2006), s. 26-32. Spôsob prístupu: http://ks.utc.sk/casopis/aktualne2.htm.

[6] ŠTOFKOVÁ, J. a kol.: Financie, EDIS Žilinská univerzita v Žiline, 2005, ISBN 80-8070501-1

[7] ŠVADLENKA L. Management v poštovních službách. První vydání. Univerzita Pardubice, 2006. 121 s. ISBN 80-7194-714-8.

\section{Grantová podpora}

Príspevok vznikol na základe riešenia výskumného projektu VEGA 1/1265/04 VEGA 1/1265/04 Výskum siet’ových procesov v rámci odvetvových zoskupení firiem v SR, podporeného MŠ SR. 